\title{
IMPACT OF CAPITAL INFLOWS AND TECHNOLOGY TRANSFER ON THE CHINESE ECONOMY
}

\author{
ZHOU XIAOBING
}

\section{THE TREND IN FOREIGN CAPITAL INFLOWS}

Since 1978, China has increasingly been making use of overseas capital for the development of its domestic economy. In retrospect, China has gone through four distinct stages.

THF INITINI. STAGE, 1979-87

During the initial stage, China began to utilise foreign direct investment (FDD). But as China's overall framework for attracting overseas capital, such as legislation, policy and infrastructure was still rather backward, overseas investors generally adopted an exploratory attitude, making only minimal direct investments in the country. During this stage, the total amount of actually utilised overseas direct investment was US $\$ 10.6$ billion-only US $\$ 1.18$ billion a year on average.

THE DEVIIOPMENT STAGE, 1988-91

During the development stage, China made great progress in utilising FDI. After the mid 1980s, China quickened its pace in enacting laws concerning FDI. The government promulgated regulations for encouraging foreign investment in October 1986, and various departments under the supervision of the State Council took steps towards implementation of the new regulations. Simultaneously, China increased its investment in the construction of infrastructure. As these measures initially improved the investment environment in China and as a consequence gained the confidence of overseas investors, direct investment in China increased rapidly. The amount of actually utilised FDI in these four years totalled US $\$ 14.44$ billion-an annual rate of US $\$ 3.61$ billion, or more than three times the prevailing annual rate during the initial stage. 
During the period 1979-91, actually utilised foreign capital mainly took the form of loans and credits which accounted for 60 per cent of foreign capital investment. In spite of a steady increase in direct investment, this form of financing only accounted for 38 per cent of the total overseas capital actually utilised up to 1991. Other forms of foreign investment accounted for the remaining 2 per cent over the same period.

\section{THF PFRIOD OF RAPID GROWTH, 1992-95}

During the rapid growth stage, the amount of overseas capital utilised by China increased dramatically. After Deng Xiaoping defined the establishment of a socialist market economy as the objective of China's economic reforms at the beginning of 1992. China picked up the pace of opening up to the outside world. From initially opening up the coastal regions, the Chinese government swiftly extended its liberalising reforms to the entire country. As a result, FDI registered tremendous growth during the period. In 1992, the amount of utilised foreign capital in China came to US $\$ 11$ billion, up by a factor of 1.5 from the previous year; and in 1993 , the figure further rose to US $\$ 27.5$ billion, up again by a factor of 1.5 from the amount in 1992. China was ranked first among the developing countries and second among all countries for its growth in foreign capital uptake. In 1994 and 1995, there was a decline in the number of foreign investment projects ratified by the Chinese government and also the amount of overseas investment agreed upon. Nonetheless, the amount of actually utilised foreign capital continued to increase to US $\$ 33.8$ billion in 1994 and to US $\$ 37.5$ billion in 1995 .

During this stage, foreign capital utilisation in China displayed several features.

- direct investment grew rapidly

- foreign-investment projects expanded in scale

- overseas investors paid more attention to obtaining control of the projects they invested in, and so there was a strong move towards sole ownership by overseas investors in newly built enterprises, and there was also a trend to expanding capital and shareholding in existing enterprises

- big transnational corporations began to enter China in large numbers, making a powerful impact on Chinese state-owned enterprises in certain industries, and securing monopolies in those industries to a certain extent

- new forms of foreign capital utilisation emerged, such as BOT, and raising funds in the securities market

- FDI became the main form of overseas capital utilised by China, surpassing overseas loans and credit in 1992 and accounting for 78 per cent of the total actually utilised overseas capital in 1995.

THE ADJUSTMENT PERIOD, 1996 ONWARDS

During this stage, China has been adjusting its policy towards the utilisation of overseas capital and trying to raise economic efficiency. In June 1995, China 
promulgated the provisional regulations for guiding the direction of overseas investment and published a catalogue of industries for guiding overseas investment. This indicates that China began to make appropriate adjustments to its policy of overseas capital utilisation - shifting the focus from the quantity of foreign capital utilised to the quality of overseas capital utilised. In fact, it was the first time that China publicly published statutes to clarify the industrial areas in which foreign investment was encouraged and permitted, and where foreign investment was restricted or even prohibited. This guide helped overseas investors to choose the right direction when making investment decisions in China.

In 1996, there was another major adjustment to China's policy towards foreign capital that concerned the reduction or remission of some of the preferential taxation arrangements enjoyed by overseas investors. A decision was made to gradually abolish the preferential taxation treatment enjoyed by foreign-invested enterprises importing capital goods. To take effect from April 1996, the decision was made with the aim of placing domestically-funded enterprises and foreigninvested enterprises on an equal and competitive footing. Following enforcement of the new policy, the number of foreign-invested projects and the amount of foreign investment agreed upon suffered decline, but the amount of actually utilised foreign capital increased steadily, rising to US\$42.35 billion in 1996 . This indicates that the scale of foreign investment and the ratio of actually paid principal have both grown. In addition, foreign investment in new and high technology industries and infrastructure has greatly increased. In 1997, FDI continued to rise rapidly, with the actually utilised amount reaching US\$51.9 billion, and accounting for 83.7 per cent of the total amount of foreign capital that year.

Over the last 20 years, the grand total of foreign capital utilised by China has accumulated to more than US $\$ 380$ billion, of which direct investment accounts for about 60.1 per cent (US\$228.5 billion), loans and credit for 36.5 per cent (US\$139 billion), and securities financing for 3.4 per cent (or US\$13 billion).

The steady decline in the number of foreign-invested projects and in the amount of agreed foreign investment in recent years will have harmful effects on the actual utilisation of foreign capital in the future. In addition, the East Asian currency crisis that appeared in the second half of 1997, resulted in a drastic devaluation of affected currencies and their weakened ability to invest abroad will have a negative impact on China's endeavours to attract overseas capital. The Chinese government has a view to maintaining the steady inflow of overseas capital, enhancing foreign capital utilisation and encouraging the importation of advanced technologies and equipment to promote China's industrial restructuring and technological progress. Hence, the Chinese government decided that from the beginning of 1998 , customs duties and taxes on imports of valueadding equipment should be remitted for the equipment imported by foreign- 
Table 13.1 Utilisation of foreign capital by China, 1979-96 (US $\$$ billion)

\begin{tabular}{lccc}
\hline Year & $\begin{array}{c}\text { Item } \\
\text { (number) }\end{array}$ & $\begin{array}{c}\text { Agreed } \\
\text { investment }\end{array}$ & $\begin{array}{c}\text { Utilised } \\
\text { investment }\end{array}$ \\
\hline $1979-82$ & 920 & 49.58 & 17.69 \\
1983 & 638 & 19.17 & 9.16 \\
1984 & 2166 & 28.75 & 14.19 \\
1985 & 3073 & 63.33 & 19.56 \\
1986 & 1498 & 33.30 & 22.44 \\
1987 & 2233 & 37.09 & 23.14 \\
1988 & 5945 & 52.97 & 31.94 \\
1989 & 5779 & 56.00 & 33.93 \\
1990 & 7273 & 65.96 & 34.87 \\
1991 & 12978 & 119.77 & 43.66 \\
1992 & 48764 & 581.24 & 110.07 \\
1993 & 83437 & 1114.36 & 275.15 \\
1994 & 47548 & 826.80 & 337.67 \\
1995 & 37011 & 912.82 & 375.21 \\
1996 & 24529 & 732.13 & 423.50 \\
Total & 283820 & 4693.90 & 1765.95 \\
& & & \\
Source: Ministry of Foreign Trade and Economic Cooperation, China. & \\
\hline
\end{tabular}

invested and domestically-funded projects, as a sign of encouragement and support from the government.

\section{THE STRUCTURE AND ROLE OF OVERSEAS DIREC'T INVESTMENT IN CHINA}

Overseas investment in China has generally taken the form of joint ventures, but the proportion of solely foreign-owned enterprises has been on the rise in recent years. Until the end of 1996, joint ventures accounted for 51 per cent of the total of actually utilised foreign capital. Solely foreign-owned enterprises and Chineseforeign cooperative enterprises accounted for 24 and 22 per cent, respectively (Table 13.2).

The majority of FDI in China originates from Hong Kong, Macao and Taiwan, with the remainder coming from the United States, Japan, Singapore, the Republic of Korea, Britain, Germany and France. To the end of 1996, 59.1 per cent of the total actually utilised foreign investment in China came from Hong Kong and Macao, with 12 per cent coming from Taiwan and 8 per cent from the United States (Table 13.3).

Foreign investment in China is mostly concentrated in secondary industries. While the tertiary sector ranks second for foreign investment, primary industry 
IMPACT OF CAPITAL INHLOWS AND TECHNOLOGY TRANSFER ON THE CHINESE ECONOMY

Table 13.2 FDI by form, 1979-96 (US\$ billion)

\begin{tabular}{lrrrrrr}
\hline & $\begin{array}{c}\text { Item } \\
\text { (number) }\end{array}$ & $\begin{array}{c}\text { Share } \\
(\%)\end{array}$ & $\begin{array}{c}\text { Agreed } \\
\text { investment }\end{array}$ & $\begin{array}{c}\text { Share } \\
(\%)\end{array}$ & $\begin{array}{r}\text { Utilised } \\
\text { investment }\end{array}$ & $\begin{array}{c}\text { Share } \\
(\%)\end{array}$ \\
\hline Joint ventures & 174014 & 61 & 2174.42 & 46 & 907.26 & 51 \\
Cooperation & 41992 & 15 & 1101.60 & 24 & 380.34 & 22 \\
Overseas-owned & 67677 & 24 & 1378.58 & 29 & 425.51 & 24 \\
Co-development & 137 &.. & 39.29 & 1 & 52.81 & 3 \\
Total & 283820 & 100 & 4693.90 & 100 & 1765.95 & 100
\end{tabular}

Source: Ministry of Foreign Trade and Economic Cooperation, China.

Table13.3 FDI by source area, 1979-96 (US\$billion)

\begin{tabular}{lrrrrrr}
\hline Country & $\begin{array}{c}\text { Item } \\
\text { (number) }\end{array}$ & $\begin{array}{c}\text { Share } \\
(\%)\end{array}$ & $\begin{array}{c}\text { Agreed } \\
\text { investment }\end{array}$ & $\begin{array}{c}\text { Share } \\
(\%)\end{array}$ & $\begin{array}{r}\text { Utilised } \\
\text { investment }\end{array}$ & $\begin{array}{c}\text { Share } \\
(\%)\end{array}$ \\
Hong Kong \& Macao & 167681 & 59.08 & 272.992 & 58.16 & 103.497 & 59.12 \\
Taiwan & 35033 & 12.33 & 34.608 & 7.37 & 15.061 & 8.53 \\
America & 22227 & 7.83 & 35.569 & 7.58 & 14.176 & 8.03 \\
Japan & 15036 & 5.30 & 25.632 & 5.46 & 14.011 & 7.93 \\
Korea & 7757 & 2.73 & 11.014 & 2.35 & 3.616 & 2.05 \\
ASEAN & 12325 & 4.34 & 23.359 & 4.98 & 9.388 & 5.32 \\
EU & 7194 & 2.53 & 25.291 & 5.39 & 8.497 & 4.81
\end{tabular}

Source: Ministry of Foreign Trade and Economic Cooperation, China.

Table 13.4 FDI by industry, 1979-95 (US\$billion)

\begin{tabular}{|c|c|c|c|c|c|c|c|c|}
\hline & $\begin{array}{l}\text { Enter- } \\
\text { prises }\end{array}$ & $\begin{array}{l}\text { Share } \\
(\%) \text { in }\end{array}$ & $\begin{array}{l}\text { Total } \\
\text { vestment }\end{array}$ & $\begin{array}{l}\text { Share } \\
t(\%)\end{array}$ & $\begin{array}{c}\text { Regist'd } \\
\text { capital }\end{array}$ & $\begin{array}{c}\text { Share } \\
(\%)\end{array}$ & $\begin{array}{c}\text { Overseas } \\
\text { paid }\end{array}$ & $\begin{array}{c}\text { Share } \\
(\%)\end{array}$ \\
\hline Primary industry & 5661 & 2 & 8.0 & 1 & 6.0 & 2 & 4.0 & 2 \\
\hline Secondary industry & 175744 & 76 & 386.5 & 61 & 258.2 & 64 & 159.0 & 62 \\
\hline Tertiary sector & 51159 & 22 & 244.5 & 38 & 134.9 & 34 & 93.9 & 36 \\
\hline Total & 233564 & 100 & 639.0 & 100 & 399.1 & 100 & 256.9 & 100 \\
\hline
\end{tabular}

Source: Wang Loulin (ed.), 1997. Report on Foreign Direct Investment in China, Economy and Management Publishing House, Beijing.

Table 13.5 FDI by region in China, 1990-94 (per cent)

\begin{tabular}{lrrrrr}
\hline Region & 1990 & 1991 & 1992 & 1993 & \multicolumn{1}{c}{1994} \\
\hline & 93.2 & 92.5 & 91.3 & 87.4 & 87.8 \\
Eastern & 4.0 & 4.5 & 6.8 & 8.9 & 7.9 \\
Central & 2.8 & 3.0 & 1.9 & 3.7 & 4.3 \\
Western & & &
\end{tabular}

Source: Institute of Industrial Economics, Chinese Academy of Social Sciences, 1997. China's Industrial Development Report 1996, China Economy and Management Publishing House, Beijing. 
accounts for only a very small percentage of total foreign investment in China. The industrial sector accounted for 62 per cent of the total actually utilised foreign capital at the end of 1996, while primary industry accounted for only 2 per cent. But since the beginning of the 1990s, the share of foreign capital invested in the industrial sector has gradually declined while the share of foreign investment in the tertiary sector has rapidly increased (Table 13.4).

Foreign investment in China is overwhelmingly concentrated in China's eastern coastal region, but the central regions have increased their share in recent years. Until 1994, China's 12 eastern provinces and regions accounted for 88 per cent of total foreign investment, but the percentage accounted for by the 9 central provinces and regions rose from 4 per cent in 1990 to 8 per cent in 1994 (Table 13.5).

The scale of foreign-invested enterprises in China has expanded on average since the beginning of the 1990s. Prior to 1990, the scale of foreign-invested projects was generally small. However, the amount of investment agreed upon for an average foreign-invested project has increased to US\$2.86 million from US\$0.92 million in 1991. An important reason for the expansion in scale has been that the ratio of actually paid principal was raised from 18.9 per cent in 1992 to 47.1 per cent in 1995.

A majority of foreign-invested enterprises have incurred losses, but not critical losses. In 1995, of all the foreign-invested enterprises already in operation, 32.6 per cent earned profits of US $\$ 400,000$ on average for an individual enterprise, but 58.7 per cent incurred losses of on average US $\$ 160,000$ for an individual enterprise. A majority of foreign-invested enterprises incurred losses, their losses were not heavy. In fact, most foreign-invested enterprises only incurred slight losses. Moreover, it should be noted that some of the foreign-invested enterprises have managed to evade taxes by transferring their profits to subsidiaries overseas. In such cases, the enterprises appeared to have incurred losses but were profitable in reality. It can therefore be assumed that there is exaggeration of the publicly declared losses reported by foreign-invested enterprises.

Table 13.6 FDI by amount of average program and the ratio of actually paid principal, 1991-95

\begin{tabular}{|c|c|c|c|c|c|}
\hline & 1991 & 1992 & 1993 & 1994 & 1995 \\
\hline Item (number) & 12978 & 48764 & 83437 & 47549 & 28000 \\
\hline Agreed investment (US\$ billion) & 11.98 & 58.12 & 111.44 & 82.68 & 80.00 \\
\hline Amount of average item $(U S \$ 000)$ & 923 & 1192 & 1336 & 1739 & 2857 \\
\hline Ratio of actually paid principal (\%) & 36.5 & 18.9 & 24.7 & 40.8 & 47.1 \\
\hline
\end{tabular}




\begin{tabular}{lrrrrr}
\hline & 1991 & 1992 & 1993 & 1994 & 1995 \\
\hline Operated (number) & $\ldots$ & 39551 & 66988 & 93453 & 108955 \\
Profits (number) & $\ldots$ & $\ldots$ & 27658 & 31229 & 35530 \\
Losses (number) & $\ldots$ & $\ldots$ & 34150 & 56111 & 63922 \\
Profits after tax paid & 1.27 & 4.19 & 8.15 & 8.35 & 14.26 \\
Losses & $\ldots$ & 2.67 & 13.75 & 8.59 & 10.27 \\
Taxation & 8.2 & 33.8 & 65.6 & 67.0 & 88.7 \\
Domestic sales & $\ldots$ & 39.7 & 72.9 & 162.0 & 158.1 \\
Export & 3.6 & 38.0 & 61.6 & 59.3 & 120.5
\end{tabular}

Source: Wang Loulin (ed.), 1997. Report on Foreign Direct investment in China, Economy and Management Publishing House, Beijing.

\section{THE IMPACT OF FOREIGN-INVESTED ENTERPRISES ON CHINA'S NATIONAL ECONOMY}

As a result of its rising share in China's GDP and as against China's own investment in fixed assets, foreign direct investment has become an important force in China's national economy. Since the early 1990s, foreign direct investment has been growing rapidly. It is estimated that from 1994 onwards, the amount of actually utilised foreign direct investment has risen to over 5 per cent of the country's GDP and more than 10 per cent of the country's investment in fixed assets.

Foreign-owned firms now accounts for half of China's total export trade and are playing a leading role in import trade. In 1996, the proportion of importexport trade operated by foreign-invested enterprises accounted for 47.3 per cent of China's total external trade ( 40.7 per cent of export and 54.5 per cent of import trade respectively).

Foreign-invested enterprises have become an important source of growth in China's foreign exchange reserves. In 1995, foreign direct investment led to an inflow of US\$33.74 billion into China. In the same year, foreign-invested enterprises incurred a deficit of US $\$ 16.06$ billion in their external trade and remitted profits of US $\$ 9.95$ billion abroad. On balance, they helped China to increase its foreign exchange reserves by US $\$ 7.72$ billion, accounting for 34.4 per cent of the total increase of China's foreign exchange reserves in that year. In addition, since the early 1990s, the foreign exchange balance of foreigninvested enterprises indicates that their yearly foreign exchange payment has consistently surpassed their foreign exchange income.

Foreign-invested enterprises have also provided jobs for a portion of China's large labour force. According to statistics, foreign-invested enterprises accounted for 10.8 per cent of China's total number of employees. By November 1997, 
APEC AND LIBERALISATION OF THE CHINESE ECONOMY

Table 13.8 FDI as a ratio of China's GDP and investment in fixed assets

\begin{tabular}{lrrrrrrr}
\hline & 1990 & 1991 & 1992 & 1993 & 1994 & 1995 & 1996 \\
\hline & & & & & & & \\
\hline $\begin{array}{l}\text { Investment in fixed } \\
\text { assets (billion yuan) }\end{array}$ & 451.70 & 559.45 & 808.01 & 1307.23 & 1704.21 & 2001.93 & 1366.00 \\
$\begin{array}{l}\text { GDP (billion yuan) } \\
\text { Utilised FDI (US\$ billion) }\end{array}$ & 3.49 & 4.37 & 11.01 & 27.52 & 33.77 & 37.52 & 42.35 \\
$\begin{array}{l}\text { Exchange rate } \\
\text { (yuan/US\$) }\end{array}$ & 4.78 & 5.32 & 5.51 & 5.76 & 8.62 & 8.35 & 8.31 \\
$\begin{array}{l}\text { FDI as ratio of GDP } \\
\text { (per cent) }\end{array}$ & 0.9 & 1.1 & 2.3 & 4.6 & 6.2 & 5.4 & 5.2 \\
$\begin{array}{l}\text { FDI as ratio of invest- } \\
\text { ment in fixed assets } \\
\text { (per cent) }\end{array}$ & 2.6 & 2.9 & 5.3 & 8.5 & 12 & 11 & 10.4
\end{tabular}

Note: According to statistics, about 70 per cent of FDI represents investment in fixed assets.

Source: Wang Loulin (ed.), 1997. Report on Foreign Direct Investment in China, Economy and Management Publishing House, Beijing.

Table 13.9 Imports and exports of FDI enterprises as a share of China's total foreign trade

\begin{tabular}{lrrrrrr}
\hline & 1991 & 1992 & 1993 & 1994 & 1995 & 1996 \\
\hline Total trade of FDI firms (1) & 28.96 & 43.76 & 67.07 & 87.65 & 109.82 & 137.11 \\
China's total foreign trade (2) & 135.63 & 166.53 & 195.71 & 236.90 & 280.86 & 289.91 \\
(1)/(2) per cent & 21.4 & 26.3 & 34.3 & 37.0 & 39.1 & 47.3 \\
FDI export trade (3) & 12.05 & 17.38 & 25.24 & 34.71 & 46.88 & 61.51 \\
China's export trade (4) & 71.84 & 84.94 & 91.74 & 121.01 & 148.78 & 151.07 \\
(3)/(4) per cent & 16.8 & 20.5 & 27.5 & 28.7 & 31.5 & 40.7 \\
FDI import trade (5) & 16.91 & 26.38 & 41.83 & 52.94 & 62.94 & 75.60 \\
China's import trade (6) & 63.79 & 80.59 & 103.96 & 115.61 & 132.08 & 138.84 \\
(5)/(6) per cent & 26.5 & 32.7 & 40.2 & 45.8 & 47.7 & 54.5
\end{tabular}

Source: State Statistical Bureau, 1997. China Statistics Yearbook 1997, China Statistical Publishing House, Beijing.

Table 13.10 The foreign exchange balance of FDI enterprises (US $\$$ billion)

\begin{tabular}{lrrrrrr}
\hline & 1990 & 1991 & 1992 & 1993 & $1994.4-12$ & 1995 \\
\hline & & & & & & \\
Foreign exchange outflow & 2.24 & 3.84 & 5.94 & 10.07 & 7.13 & 14.14 \\
Foreign exchange inflow & 1.24 & 2.19 & 3.54 & 4.01 & 4.01 & 9.22 \\
Foreign exchange balance & 1.01 & 1.65 & 2.42 & 6.06 & 3.12 & 4.92
\end{tabular}

Source: Ministry of Foreign Trade and Economic Cooperation, China. 
145,000 foreign-invested enterprises existed in China with a total payroll of US\$17.5 million.

Taxes paid by foreign-invested enterprises have increased rapidly. Taxes paid by foreign-invested enterprises accounted for 2.3 per cent of China's total tax revenue in 1991. The figure increased to 7.6 per cent in 1994 at 39 billion yuan.

Overseas capital has played a considerable role in promoting the development of China's economy (Table 13.11). Since the early 1990s particularly, foreigninvested enterprises have become a significant force that affects China's overall performance in terms of investment, foreign trade, foreign exchange, employment, and taxation revenue.

Foreign-invested enterprises have also played a positive role in promoting restructuring and the internationalisation of the Chinese economy in several ways.

- They have introduced China to the mechanisms of market and competition and have brought competition to bear upon Chinese national enterprises, helping raise awareness of competition and its place in the market.

- They have helped China's state-owned enterprises to transform their management practices. Joint ventures combining foreign-invested enterprises and the Chinese state-owned enterprises have compelled the state-owned enterprises to transform their existing management practices. In addition, foreign-owned enterprises have led the way in management innovation, showing the way for Chinese state-owned enterprises to transform their own management strategies.

- Foreign-invested enterprises have also promoted China's reform of the institutional framework in order to conform with international best practice. Production and management in foreign-invest enterprises are all conducted according to international best practice, which is incompatible with China's traditional economic structure. Now that the Chinese government is keen to be the host for vast amounts of overseas capital, the traditional economic structure must be transformed so that laws and institutions enforce international best practice.

- Foreign-invested enterprises have helped to strengthen relations between the Chinese economy and the world economy. Foreign-invested enterprises are familiar with the world market and are much more outward-looking than Chinese state enterprises. They have not only helped the Chinese authorities develop contacts in the world market, but have also helped Chinese state enterprises to develop a more outward-oriented focus.

\section{CHALLENGES AND PROBLEMS CAUSED BYTHE MASSIVE INFLOW OF OVERSEAS CAPITAL}

Foreign-invested enterprises have brought competitive pressures to bear upon China's domestic enterprises. Brisk expansion in inflows of overseas capital has 
Table 13.11 Taxes paid by FDI enterprises as a proportion of China's total tax revenue (billion yuan)

\begin{tabular}{lrrrr}
\hline & 1991 & 1992 & 1993 & 1994 \\
\hline & & & & \\
Taxes paid by FDI (1) & 6.9 & 10.7 & 20.6 & 39.0 \\
Total tax revenue (2) & 299.0 & 329.7 & 425.5 & 512.7 \\
(1)/(2) per cent & 2.3 & 3.2 & 4.8 & 7.6 \\
Source: Institute of Industrial Economics, Chinese Academy of Social Sciences, 1997. China's Industrial \\
Development Report 1996, China Economy and Management Publishing House, Beijing.
\end{tabular}

made a substantial impact on China's domestic economy. Even in the home market, a number of local Chinese enterprises are confronted with competitive pressures similar to those found in the world market. On the one hand, foreigninvested enterprises enjoy preferential treatment which local firms cannot access. On the other hand, foreign-invested enterprises have a number of competitive advantages with respect to technology, sales, and branding in addition to capital and management techniques; in all of which Chinese enterprises are disadvantaged.

In certain industries, foreign-invested enterprises maintain a dominant or controlling position. Overseas investors have managed to dominate certain industries by establishing entirely foreign-owned enterprises or by acquiring majority share ownership in joint ventures. In selecting avenues for investment, overseas investors have concentrated their investment in industries with high rates of profit. More specifically, they tend to invest in downstream industries that produce end products. In this way, most industries with high costs and low profits are left to Chinese enterprises. Overseas capital has maintained a dominant position in certain highly profitable industries, and has constituted a high proportion of the exclusive investment and holding companies.

The Chinese government has paid much attention to the quantity of the overseas capital imported but is not good at managing it. This has resulted in a number of problems.

- There is no accurate asset appraisal; the Chinese government's assets are often under-valued or even partially neglected.

- Since overseas capital is concentrated in certain industries and certain regions, there is a tendency towards foreign dominance in those industries and regions.

- There are no enforced regulations on the transfer of pollution in certain industries.

- In foreign-invested enterprises, there is often insufficient social insurance for Chinese employees whose working conditions are generally poor. 
Much of the overseas capital flowing into China was unaccompanied by new and advanced foreign technologies. Most joint ventures have been small scale and have utilised existing technologies, generally engaged in the processing and trade industries that have had little to do with advanced technologies. The technologies brought to China by big transnational corporations have not been advanced, and have generally been imported for standardising production and processing. Moreover, the governments of many industrial countries restrict transfer of new and advanced technologies to foreign countries. In addition, when transnational corporations make investments in China, they often refuse to establish research and development programs, sometimes cancelling existing programs in order to use the technologies developed by their parent companies. As a result, the ability of Chinese firms to develop technologies in conjunction with foreign enterprises in joint ventures is weakened.

\section{PROSPECTS FOR FOREIGN CAPITAL}

In the near future, the Chinese government will direct efforts at maintaining the level of capital inflow, because foreign capital has become an important factor for China's economic stability in the short term. First, since the massive inflows of foreign capital have occupied a significant position in China's national economy, a sudden decrease may have a great impact on the country's domestic economy. Second, owing to the depreciation of currencies in neighbouring countries following the East Asian financial crisis of 1997, China has had to bear reduced demand for exports for a period of time. As a consequence, export trade can no longer be the driving force for economic growth and overseas investment will have to take its place. Hence there is a need to maintain stability in foreign capital inflows. Third, a decline in exports could cause deficits in the current account, which would have to be offset by a surplus in the capital account to balance international payments, again highlighting the need to maintain foreign capital inflows.

In the long term, the importation of overseas capital should shift in emphasis from quantity to quality. As properly functioning markets are established in China, market forces should attract overseas capital as opposed to the preferential treatment that foreign investment now receives such as reductions in or the remission of tax payments. The benefits associated with fully-functioning markets are obvious. First, they will enable Chinese enterprises to compete with foreigninvested enterprises on an equal footing. Second, market forces will prompt foreign-invested enterprises to increase their sales in the Chinese domestic market, which may lighten China's dependence on foreign trade, and may also help overseas investors to turn their eyes to China's interior regions. A shift to more indirect forms of foreign investment, such as foreign loans and credits will 
enable China to take the initiative in regard to promoting industrial adjustment and the importation of technology. International indirect investment presents no difficulty as far as possible conflicts over the objectives of the investment are concerned, as recipient countries are free to purchase technology and equipment in the world market according to their industrial and technological requirements.

\section{TECHNOLOGICAL TRANSFERAND ITS IMPACT}

\section{A GENERAL SURVEY OF TECHNOLOGICA4 TRANSFER TO CHINA}

In the early $1980 \mathrm{~s}$, China changed the emphasis on technological importation from the importing of technology for new large-scale projects to the importing advanced technologies for transforming existing enterprises. During the Sixth Five-year Plan (1981-85) and the Seventh Five-year Plan (1986-90), 30,000 technological items were imported for the light and textile industries, in addition to the machinery and electronic industries. During the Eight Five-year Plan (199195), and apart from the continued importation of technologies for transforming old enterprises, China imported a number of technologies destined for major projects in energy, petrochemistry, metallurgy, aviation, machinery and electronics.

The Chinese government tended to import technologies for major projects and large and medium-scale enterprises. The technological transformation of medium and small-scale enterprises was basically dependent upon foreign direct investment.

\section{IMPACT OF TECHNOLOGICAL TRANSFER ON CHINA'S ECONOMIC DEVELOPMENT}

The importation of technology and equipment has significantly raised the technological standard among Chinese enterprises. An important form of China's importation of technology has been to sign contracts to import equipment. In this way both the machinery and advanced technology are purchased simultaneously. During the Eighth Five-year Plan, expenditure on the importation of technology was US $\$ 23$ billion, registering an increase of 48 per cent as compared with that during the Seventh Five-year Plan. Following the massive inflow of overseas capital into China, the importation of equipment grew rapidly and began to occupy a considerable proportion of China's total imports. It is estimated that during the Eighth Five-year Plan, expenditure on imported machinery and transport equipment accounted for nearly 40 per cent of the country's total expenditure on imports.

Advanced or fairly advanced equipment accounted for about one-third of total equipment imported during the Eighth Five-year Plan, at a value of around US $\$ 150$ billion. Imported equipment included textile machinery, machine tools for metal processing, machinery for rubber and plastics processing, instruments, 
and machinery for loading and unloading. By the end of the Eighth Five-year Plan about half of the large and medium-scale state-owned enterprises had gone through considerable technological transformation with the aid of imported advanced technologies and equipment. Among the state-owned enterprises, those engaged in producing goods for export underwent the most comprehensive technological transformation.

Imports of technology and equipment have expanded the productive capacity and technical level of China's export processing industry. As a result, there has been a considerable increase in the production of export goods. At present, manufactured goods are in a dominant position relative to other export goods. During the Eighth Five-year Plan, the proportion of imports and exports of manufactured industrial products in China's total foreign trade increased from 77.7 per cent in 1991 to 83.7 per cent in 1995 . The growth in exports of machinery and electrical products and textiles was the most dramatic. In 1985, exports of

Table 13.12 Technology import projects and contracted value by type of import (contract numbers, value in US\$ million)

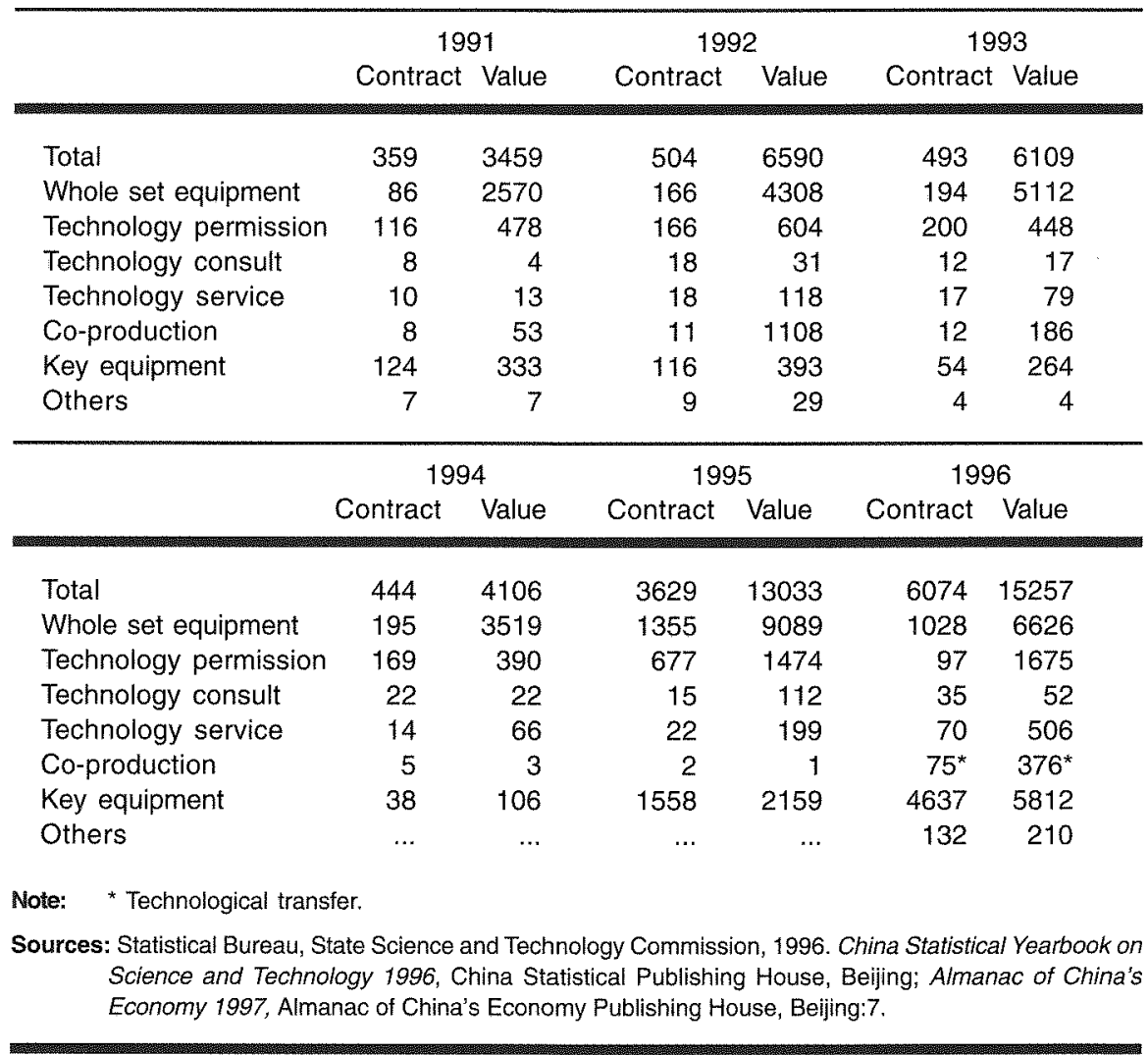


Table 13.13 Technology import projects and contracted value by type of import (US\$ million)

\begin{tabular}{lrrrrrr}
\hline & 1991 & 1992 & 1993 & 1994 & 1995 & 1996 \\
\hline Total & 3459 & 6590 & 6109 & 4106 & 13033 & 15257 \\
Energy & 1547 & 1464 & 1138 & 682 & 3593 & 1361 \\
Machinery, electronics & 384 & 1909 & 546 & 248 & 3965 & 2331 \\
Petro-chemistry & 1121 & 2045 & 2600 & 605 & 1104 & 3068 \\
Communication and traffic & 162 & 120 & 427 & 1348 & 1814 & 3236 \\
Metallurgy & 86 & 602 & 709 & 726 & 1282 & 1356 \\
Construction materials & 5 & 1 & 49 & 47 & 473 & 438 \\
Light Industry and textiles & 105 & 328 & 355 & 405 & 473 & 1022 \\
Others & 50 & 119 & 285 & 47 & 329 & 2445
\end{tabular}

Source: Statistical Bureau, State Science and Technology Commission, 1996. China Statistical Yearbook on Science and Technology 1996, China Statistical Publishing House, Beijing; Almanac of China's Economy 1997, Almanac of China's Economy Publishing House, Beijing:7.

machinery and electrical products only accounted for 6.5 per cent of China's total export trade. The figure leapt to 29.5 per cent in 1995 , surpassing that of the textiles for the first time. Currently, mechanical and electrical products rank as the most important export goods. As for textiles, the proportion of medium and low-grade products in China's total textile trade decreased from 50 per cent in the 1980s to less than 20 per cent in the latter years of the Eighth Five-year Plan. In contrast, the proportion of end products like garments rose from 50 per cent to over 80 per cent during the same period.

The electronic and machinery industries have benefited most from using overseas investment to raise their technological levels. According to a survey of the electronic industry in 1995, the aggregate quantity of equipment owned by an individual Chinese enterprise surpassed that owned by foreign-invested enterprises by 44.9 per cent on average, but the quantity of imported equipment, automatic production lines and computers owned by foreign-invested firms greatly surpassed that of Chinese enterprises. Moreover, a portion of the advanced equipment owned by Chinese enterprises was acquired with the help of overseas capital. It is clear that overseas investment has played a large role in promoting technological progress of the Chinese electronic industry. According to a survey conducted in 1995 investigating foreign-invested enterprises in the machinery industry, their technological level overall reached the international standard of the 1980s, while some individual enterprises reached the international standard of the early 1990s.

The importation of technology has prompted domestic enterprises to raise their management performance and the quality of their human capital. To equip Chinese enterprises with advanced technology and equipment inevitably demands 
a corresponding rise in the quality of management practices, workers and staff in order to make the most of the advanced technology and equipment. Moreover, the importation of technology generally includes support services such as technical training and technical guidance. In addition, the nature of imported technologies has changed from operational technologies to mainly manufacturing technologies.

\section{PROBLEMS IN THE TRANSFER OF TECHNOLOGY}

Among the technologies imported with foreign direct investment, there are not many genuinely advanced technologies. The technologies imported by medium and small-scale enterprises are technically low grade. Especially in the case of enterprises engaged in processing industries, the Chinese party can only earn processing rebates without acquiring much technology. Small and medium-scale enterprises are great in number, and produce goods that account for about half of the total value of China's export trade. In particular, processing firms in 1994 produced 71 per cent of total exports of mechanical and electrical products.

Table 13.14 Exports and imports of high-tech products, manufactured industrial products and primary products (US\$ billion)

\begin{tabular}{lrrrrrr}
\hline & 1987 & 1988 & 1990 & 1993 & 1994 & 1995 \\
\hline I. Total foreign trade & 82.65 & 102.79 & 115.41 & 195.71 & 236.73 & 280.85 \\
Manufactured prod. & 62.51 & 78.29 & 89.70 & 164.82 & 200.56 & 234.95 \\
share (per cent) & 75.6 & 76.2 & 77.7 & 84.2 & 84.7 & 83.7 \\
High-tech prod. & 6.31 & 9.42 & 9.65 & 20.58 & 26.94 & 31.92 \\
share (per cent) & 7.6 & 9.2 & 8.4 & 10.5 & 11.4 & 11.4 \\
Primary prod. & 20.15 & 24.50 & 25.71 & 30.89 & 36.18 & 45.90 \\
share (per cent) & 24.4 & 23.8 & 22.3 & 15.8 & 15.3 & 16.3 \\
II. Export & 39.44 & 47.54 & 62.06 & 91.76 & 121.04 & 148.77 \\
Manufactured prod. & 26.21 & 33.11 & 46.21 & 75.09 & 101.33 & 127.28 \\
share (per cent) & 66.4 & 69.6 & 74.5 & 81.8 & 83.7 & 85.6 \\
High-tech prod. & 0.92 & 1.29 & 2.69 & 4.68 & 6.34 & 10.09 \\
share (per cent) & 2.3 & 2.7 & 4.3 & 5.1 & 5.2 & 6.8 \\
Primary prod. & 13.23 & 14.43 & 15.86 & 16.68 & 19.71 & 21.49 \\
share (per cent) & 33.6 & 30.4 & 25.5 & 18.2 & 16.3 & 14.4 \\
III. Import & 43.21 & 55.25 & 53.35 & 103.95 & 115.69 & 132.08 \\
Manufactured prod. & 36.30 & 45.18 & 43.50 & 89.73 & 99.22 & 107.67 \\
share (per cent) & 84.0 & 81.8 & 81.5 & 86.3 & 85.8 & 81.5 \\
High-tech prod. & 5.32 & 8.13 & 6.97 & 15.91 & 20.60 & 21.83 \\
share (per cent) & 12.5 & 14.7 & 13.1 & 15.3 & 17.8 & 16.5 \\
Primary prod. & 6.92 & 10.7 & 9.85 & 14.22 & 16.47 & 24.41 \\
share (per cent) & 16.0 & 18.2 & 18.5 & 13.7 & 14.2 & 18.5
\end{tabular}

Source: Statistical Bureau, State Science and Technology Commission, 1996. China Statistical Yearbook on Science and Technology 1996, China Statistical Publishing House, Beiling. 
The transfer of technology from big transnational corporations has tended to be more basic technology used in the standardisation of production and processing. Moreover, foreign governments often restrict the transfer of new and advanced technology to other countries.

China's ability to assimilate advanced technology is still limited. China's scientific research institutions and enterprises are relatively independent of each other, but relations between the two have become closer since the start of economic restructuring. Nonetheless, the research and development capabilities of Chinese enterprises are rather poor. Although there is a policy of markets for technology there are still many difficulties in its implementation. The process of technological transfer is stepwise and overseas parties tend to impose conditions. The pace of technology transfer is controlled within the limits of China's technological development. For Chinese parties, if the imported technology exceeds the firms' ability to assimilate it, the technology is useless in raising the firms' efficiency. In the worst case, imported equipment may be left unused or damaged. This kind of problem was prevalent in the 1980s. Since the 1990s, large-scale enterprises have paid attention to raising their ability to assimilate advanced technologies, but the medium and small-scale enterprises still have a weakness in this regard.

\section{THE TREND OF TECHNOLOGY TRANSFER}

The aggregate quantity of technology transferred will remain at a high level. At present, China has accumulated substantial foreign exchange reserves and Chinese enterprises have gone from strength to strength. The Chinese government also has encouraged domestic enterprises to engage in technological transformation by utilising advanced technologies from overseas. Moreover, many enterprises in coastal regions are under pressure to upgrade their capital equipment, and

Table 13.15 Scientific and technological research institutions (numbers)

\begin{tabular}{lrrrr}
\hline & 1990 & 1994 & 1995 & 1996 \\
& 18772 & 23613 & 24259 & 23610 \\
Total & 8990 & 7805 & 7721 & 7636 \\
$\begin{array}{l}\text { In research institutions } \\
\text { In large and medium } \\
\text { industrial enterprises }\end{array}$ & 8116 & 12499 & 13107 & 12033 \\
$\begin{array}{l}\text { In institutions of higher } \\
\text { education }\end{array}$ & 1666 & 3309 & 3431 & 3398
\end{tabular}

Source: State Statistical Bureau, 1997. China Statistical Yearbook 1997, China Statistical Publishing House, Beijing. 
Table 13.16 Technology import projects and contracted value by region of import (number; US\$ million).

\begin{tabular}{|c|c|c|c|c|c|c|}
\hline & \multicolumn{2}{|c|}{1991} & \multicolumn{2}{|c|}{1992} & \multicolumn{2}{|c|}{1993} \\
\hline & Contract & Value & Contract & Value & Contract & Value \\
\hline Total & 359 & 3459 & 504 & 6590 & 493 & 6109 \\
\hline Japan & 63 & 269 & 136 & 1376 & 101 & 1746 \\
\hline USA & 54 & 135 & 85 & 1432 & 104 & 507 \\
\hline Germany & 54 & 265 & 70 & 733 & 83 & 748 \\
\hline Italy & 28 & 353 & 44 & 1444 & 53 & 922 \\
\hline Russia & 9 & 1374 & 6 & 245 & 14 & 383 \\
\hline France & 35 & 194 & 22 & 383 & 17 & 175 \\
\hline Spain & 9 & 246 & 5 & 388 & 6 & 442 \\
\hline UK & 21 & 344 & 25 & 22 & 10 & 116 \\
\hline Canada & 7 & 67 & 13 & 181 & 14 & 188 \\
\hline Hong Kong & 28 & 20 & 35 & 76 & 21 & 42 \\
\hline Austria & 10 & 25 & 9 & 67 & 9 & 120 \\
\hline Korea & & & 3 & 17 & 8 & 304 \\
\hline Switzerland & 9 & 14 & 17 & 62 & 13 & 128 \\
\hline Finland & & & 6 & 89 & 7 & 152 \\
\hline Sweden & 6 & 18 & 3 & 10 & 8 & 11 \\
\hline Australia & & & & & & \\
\hline \multirow[t]{3}{*}{ Others } & 26 & 135 & 25 & 66 & 25 & 125 \\
\hline & \multicolumn{2}{|c|}{1994} & \multicolumn{2}{|c|}{1995} & \multicolumn{2}{|c|}{1996} \\
\hline & Contract & Value & Contract & Value & Contract & Value \\
\hline Total & 444 & 4106 & 3629 & 13033 & 6074 & 15257 \\
\hline Japan & 94 & 769 & 533 & 2249 & 925 & 2404 \\
\hline USA & 75 & 594 & 798 & 2272 & 1744 & 2130 \\
\hline Germany & 67 & 1232 & 398 & 1892 & 705 & 4907 \\
\hline Italy & 31 & 311 & 153 & 977 & 196 & 470 \\
\hline Russia & 2 & 4 & 285 & 759 & 194 & 1177 \\
\hline France & 26 & 195 & 78 & 1706 & 220 & 614 \\
\hline Spain & 4 & 95 & 28 & 275 & 30 & 177 \\
\hline UK & 12 & 75 & 82 & 718 & 134 & 201 \\
\hline Canada & 12 & 268 & 62 & 204 & 115 & 384 \\
\hline Hong Kong & 34 & 134 & 674 & 586 & 1021 & 922 \\
\hline Austria & 8 & 34 & 45 & 303 & 69 & 300 \\
\hline Korea & 7 & 84 & 38 & 103 & 56 & 150 \\
\hline Switzerland & 8 & 10 & 86 & 188 & 136 & 194 \\
\hline Finland & 4 & 17 & 22 & 101 & 37 & 199 \\
\hline Sweden & 35 & 105 & 72 & 210 & 115 & 326 \\
\hline Australia & 5 & 84 & 24 & 74 & 49 & 208 \\
\hline Others & 20 & 95 & 251 & 416 & 264 & 385 \\
\hline
\end{tabular}

Source: Statistical Bureau, State Science and Technology Commission, 1996. China Statistical Yearbook on Science and Technology 1996, China Statistical Publishing House, Beiling; Almanac of China's Economy 1997, Almanac of China's Economy Publishing House, Beijing:7. 
need to import advanced foreign technologies and equipment to do so. These factors will give an added impetus to the transfer of technology.

The ability of Chinese enterprises to assimilate advanced technologies will gradually increase, and the mode of technology transfer will shift from predominantly importing entire plants to importing key pieces of equipment and acquiring technological licenses. As a result, the average scale of technological equipment imported will gradually become smaller and more medium and smallscale enterprises will be able to import the advanced technology required to increase their productivity and efficiency.

The sources of China's technology will remain diverse and relatively balanced. In the early 1990s, China imported technology mainly from Europe due to international political concerns. Since 1992, and owing to the gradual normalisation of Sino-US relations, China's technological imports from the United States and Japan have increased rapidly. Now that the configuration of China's political and economic relations with the outside world have fundamentally been settled, it is expected that the sources of China's technology will retain the present balance among Europe, the United States and Japan.

Progress in economic and technological cooperation within the APEC framework will play an important role in promoting the transfer of technology to China and technological cooperation with China. Economic and technological cooperation is one of the APEC's two aims, the other aim being the liberalisation of investment and trade. APEC member countries have responded to these aims, taking action to cooperate and liberalise to various degrees. China has proposed that a network for high-tech cooperation among APEC member countries be established, and has listed its 53 new and high technological development zones as the first batch of sci-tec industrial parks to be opened to APEC members. China's initiatives have received a positive response from some countries. In sum, the strengthening of technological cooperation among APEC members will not only facilitate the transfer of advanced technologies to China from overseas, but will also enhance the ability of Chinese enterprises to assimilate and develop that technology, empowering China to import more advanced foreign technology. 